Superior School of Technology

Morroco

Seddik Bri

Full Professor

University Moulay Ismail

Superior School of Technology

Meknes

Morroco

Jaouad Foshi

Full Professor

University Moulay Ismai

Faculty of Science and Technology

Errachidia

Morroco \section{Composites \\ Dielectric Properties of SiCf/SiC}

The aim of this recherch work is to present a study of the microwave dielectric properties of three dielectric composites of periodic structure with Nicalon SiC fiber, Hi-Nicalon SiC fiber and SCS6 SiC fiber which are incorporated in a ceramic matrix $\mathrm{SiC}(\mathrm{SiCf} / \mathrm{SiC})$. The simulated values of the complex permittivity were compared to those obtained by different mixing laws using finite element method. McLachlan's theory is able to predict the effective permittivity of the structures studied, even for a high volume fraction and a high contrast. Dielectric properties behavior of these composites at the microwave frequencies in $X$ band can be accurately fitted by the Generalised Looyenga law if adjusting the value of the exponent $h$. The obtained values for the exponent parameter of this law allow inferring the particles shape.

Keywords: Dielectric properties, mixture laws, Finite element method, microwave, Composite materials.

\section{INTRODUCTION}

The electrical properties of heterogeneous media are important in many branches of science, in colloid physics and chemistry [1]. On the one hand, it provides basic problems that are not completely answered, for example, metal-insulator transition [2]. On the other hand, industries such as aerospace, electronics and others have consistently provided the impetus pushing the development of new materials in a wide variety of applications [3]. The dielectric properties of a heterogeneous medium depend on the permittivity of the component materials, their volume fractions and the form of inclusions [4]. The determination of the effective permittivity depends upon the degree of complexity of the composite structure [5]. If the mixture has a periodic structure, the effective permittivity can be evaluated analytically under certain conditions (forms dispersions, electric field orientation) by mixture laws. In contrast, for media whose structure is disordered, there are no rigorous solutions, nor any systematic methods for calculating the effective permittivity [1-3]. The multitude of mixture laws mentioned in the literature reflects these challenges $[1,6]$. The ceramic matrix materials $\mathrm{SiC}$ reinforced by $\mathrm{SiC}$ fiber, can produce composites with interesting dielectric proper-ties. The relatively stable dielectric properties at high temperatures of these materials are also demonstrated in many practical and potential applications of microwave absorption at high temperatures [7]. These composites are found in combus1tion chambers, Braking systems are used in the aeronautics and automotive sectors as well as in tanks [8]. In this article, we intend to summarize the basic theoretical

Received: July 2017, Accepted: September 2017

Correspondence to: My Chrif El boubakraoui

Superior School of Technology

Rue Agourai, Meknes, Morroco

E-mail: charif2060@gmail.com

doi:10.5937/fmet1801086E

(C)niversity Moulay Ismail, Meknes. All rights reserved methods and to systematize the resulting formulae. The formulae will be compared numerically using three different composites with different contrasts. In a later publication, the complex dielectric behavior (frequency dependent) and microwave properties will be discussed.

\section{THEORIES AND METHODS}

\subsection{Classical mixture laws}

In a homogeneous medium, the permittivity is independent of the variables of space; it keeps the same value at all points. On the contrary, heterogeneous mediums are represented by an average effective permittivity. This is possible if the size of heterogeneities is small in comparison with the wavelength of the signal.

The principal problems concerning the intrinsic properties of the constituents are the volume fractions of inclusions, the multipolar interactions which are not taken into consideration, the geometric shape of the inclusions and the distribution of the particles in the matrix fronting the external electric field [6]. In the hypothesis of long wavelengths, the medium can be considered as a homogeneous medium characterized by effective permittivity under the condition $|\mathrm{kd}|<1$ with $k=\frac{\omega}{c} \sqrt{\varepsilon \mu}$ which represents the wave vector associated with inclusions of the permittivity $\varepsilon$ and the permeability $\mu$, and defines the typical size of reinforcement particles.

The effective dielectric permittivity of the composite describing the relationships between the microscopic and macroscopic properties of heterostructures and their constitutions has been described by many analytical formulas and theories called mixture laws.

The Maxwell-Garnett theory is based on induced polarization by a uniform external electric field applied to spherical inclusions disposed in a matrix $[6,9]$. The effective permittivity is given by the following equation: 


$$
\varepsilon_{e f f}=\varepsilon_{m}+3 p \varepsilon_{m} \frac{\varepsilon_{k}-\varepsilon_{m}}{\varepsilon_{k}+2 \varepsilon_{m}-p\left(\varepsilon_{k}-\varepsilon_{m}\right)}
$$

$\mathrm{p}$ is the volume fraction. $\varepsilon \mathrm{m}$ and $\varepsilon \mathrm{k}$ are the permittivity of matrix and inclusions respectively.

Another theory is provided by Bruggman (approximate effective medium model) is given by the equation:

$$
(1-p) \frac{\varepsilon_{m}-\varepsilon_{e f f}}{\varepsilon_{m}+\varepsilon_{e f f}}+p \frac{\varepsilon_{k}-\varepsilon_{e f f}}{\varepsilon_{k}+\varepsilon_{e f f} 0}=0
$$

In the Bruggeman model, the hypothesis of the existence of explicit host material is not considered [79]. The particles of all components are assumed encased in an effective medium permittivity equal to the effective permittivity eeff of mixture that we try to find. Another interesting equation has been developed by Looyenga [12], who assumed that by mixing two constituents whose permittivities are such that $\varepsilon_{\mathrm{k}}=\varepsilon_{\text {eff }}$ $\Delta \varepsilon_{\mathrm{ff}}$ and $\varepsilon_{\mathrm{k}}=\varepsilon_{\mathrm{eff}}+\Delta \varepsilon_{\mathrm{ff}}$. Generalised Looyenga law may be written in the following form:

$$
\varepsilon_{\text {eff }}=\left[\varepsilon_{m}^{1 / h}+p\left(\varepsilon_{k}^{1 / h}-\varepsilon_{m}^{1 / h}\right)\right]^{h}
$$

where $\mathrm{h}=3$ in the case of spherical inclusions and $\mathrm{h}=$ 1.76 in the case where the inclusion has a fiber form [10].

For $\mathrm{h}= \pm 1$, we find the Wiener terminals that represent situations or laminated materials are parallel or perpendicular to the external electric field [13].

$$
\begin{aligned}
& \varepsilon_{\text {eff } / /}=p \varepsilon_{k}+(1-p) \varepsilon_{m} \\
& \varepsilon_{\text {eff } \perp}=\frac{\varepsilon_{k} \varepsilon_{m}}{p \varepsilon_{m}+(1-p) \varepsilon_{k}}
\end{aligned}
$$

Lichtenecker and Rother proposed a mathematical model for the determination of the dielectric constant of a mixture composed of two constituents. It is given by [14]:

$$
\ln \varepsilon_{\text {eff }}=p \ln \varepsilon_{k}+(1-p) \ln \varepsilon_{m}
$$

The model McLachlan, or generalized effective medium equation, is valid for low and high concentrations of inclusions to near the percolation threshold. It is explicit from the following equation [13]:

$$
(1-p) \frac{\varepsilon_{m}^{1 / s}-\varepsilon_{e f f}^{1 / s}}{\varepsilon_{m}^{1 / s}+\left(\frac{1-f_{p}}{f_{p}}\right) \varepsilon_{m}^{1 / s}}+p \frac{\varepsilon_{k}^{1 / t}-\varepsilon_{e f f}^{1 / t}}{\varepsilon_{k}^{1 / t}+\left(\frac{1-f_{p}}{f_{p}}\right) \varepsilon_{k}^{1 / t}}=0
$$

where $\mathrm{fp}$ is the percolation threshold of the inclusions and $p$ is the volume fraction. The two exponent $t$ and $s$ determine the divergent behavior near of the percolation threshold. These values are different from one composite to another. In agreement with the standard percolation theory, $\mathrm{t}$ and $\mathrm{s}$ are highly dependent on the geometry of the inclusions. This model combines bet- ween the McLachlan classical approach of effective medium and the percolation theory [16].

\subsection{Physical model and finite element method}

The method of calculating the effective permittivity of heterogeneous structures proceeds in three steps: (i) Definition of the unit cell. The space is filled by calculating the desired arrangement and relative permittivity $\varepsilon_{1}$ and $\varepsilon_{2}$ are assigned to the matrix and inclusions respectively. (ii) Automatic Generation of fine mesh allows a very good approximation of the space (iii) Calculation of the spatial distribution of local potential within the computational domain where there are no free charges or currents. This distribution is obtained by solving the equation (8).

Our simulation of the effective complex dielectric constants of binary-phase composites is performed on the model as shown in Figure 1. A parallel plate capacitor, with conducting planes of areas $\mathrm{S}$ and separation $h$ is filled with a statistically isotropic composite dielectric, consisting of two isotropic lossy materials with complex dielectric constants $\varepsilon_{1}$ and $\varepsilon_{2}$. A potential difference $U$ is applied on this capacitor.

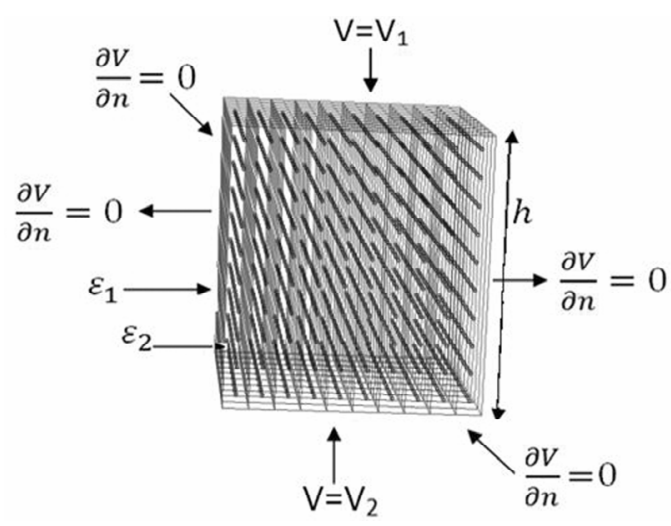

Figure 1. Structure of the periodic composite studied

As the finite element method is known for its gluttony of memory and computing time, we restrict to studying structure through simulations of the unit cells shown in Figure 2.The material is exposed to a static electric field that is generated by a voltage between the opposite faces of the unit cell [2, 6, 17-19].

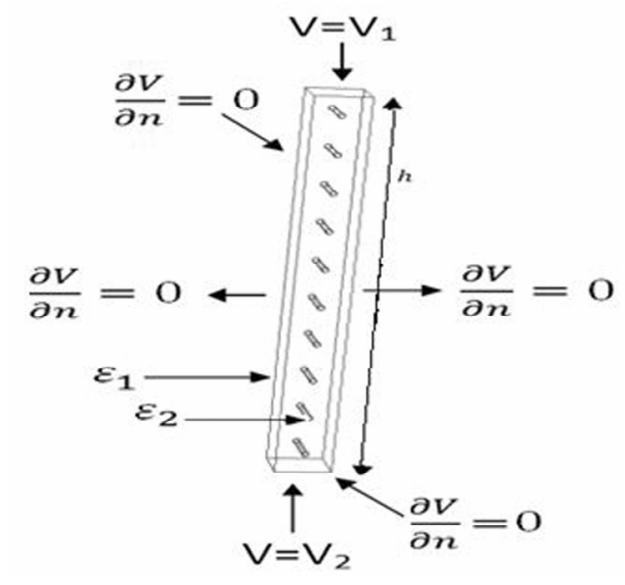

Figure 2. Boundary conditions of the field problem in the unit cell of the studied composite. 
The potential distribution is determined from the Laplace equation inside the unit cell [18-19].

$$
\nabla\left(\varepsilon_{0} \varepsilon_{r} \nabla U\right)=0
$$

Solving the Laplace equation $(\Delta \mathrm{V}=0)$ in a threedimensional domain mathematically equivalent to minimizing the energy function corresponding to the stored electrostatic energy in space, relative to the values of the potential at the nodes of the mesh elements $[3,16,18]$ :

$$
W=\frac{1}{2} \iiint \varepsilon(x, y, z)\left[\left(\frac{\partial V}{\partial x}\right)^{2}+\left(\frac{\partial V}{\partial y}\right)^{2}+\left(\frac{\partial V}{\partial z}\right)^{2}\right] d x d y d z
$$

In this problem, we consider a portion of the composite material filling a plane capacitor. That way, we obtain the effective permittivity in the direction of the applied field, from the energy stored in such a capacitor when a voltage is applied to its plates $[18,21]$ :

$$
W=\frac{1}{2} \varepsilon_{0} \varepsilon_{e f f} \frac{S}{h}\left(V_{2}-V_{1}\right)^{2}
$$

A potential difference $\mathrm{V} 1-\mathrm{V} 2=1 \mathrm{~V}$ is applied to the upper and lower planes of the unit cell. The periodic boundary conditions $\partial \mathrm{V} / \partial \mathrm{n}=0$ are assigned on the planes perpendicular to $\mathrm{x}$ and $\mathrm{y}$ directions, where $\mathrm{n}$ is the unit vector normal output.

\subsection{Proposed microwave method}

The technique proposed is a transmission / reflection (T/R) characterized by $3 \mathrm{D}$ simulations. It is iterative, requiring only one sample of the material to be characterized. The technique involves placing the sample of material under test inside the rectangular waveguide and measuring the $S_{\mathrm{ij}}$ parameters. It is assumed that the sample is isotropic, symmetric, homogeneous and non-magnetic. We also assume that only the dominant mode $\left(\mathrm{TE}_{10}\right)$ is present inside the waveguide and that the sample is precisely adjusted in its compute cell.

We calculate the corresponding transmission matrices according to the following equation [22-24]:

$$
M_{i}=\frac{1}{S_{21 i}}\left(\begin{array}{cc}
S_{12 i} S_{21 i}-S_{11 i} S_{22 i} & S_{11 i} \\
-S_{22 i} & 1
\end{array}\right), i=1 \text { or } 2
$$

$\mathrm{M}_{1}$ : corresponds to the compute cell which is empty or partially filled by a dielectric whose complex permittivity is known with precision on the frequency band studied.

$\mathrm{M}_{2}$ : corresponds to the compute cell partially filled by the sample to be characterised the material under test.

The matrix $\mathrm{M}_{\mathrm{i}}$ can be written in the form of a product of five matrices:

$$
M_{i}=X \cdot T_{r e f i} \cdot T_{i} \cdot T_{r e f i}^{-1} \cdot Y
$$

$\mathrm{X}$ and $\mathrm{Y}$ : the error matrices assumed to be unchanged during the two computes.

$\mathrm{T}_{\text {refi }}$ : The transmission matrix corresponding to the impedance jump at the Air/Material interface.

$$
T_{r e f i}=\frac{1}{1-\Gamma_{i}}\left(\begin{array}{cc}
1 & \Gamma_{i} \\
\Gamma_{i} & 1
\end{array}\right)
$$

where $\Gamma_{i}=\frac{i_{0}-i_{1}}{\gamma_{0}+\gamma_{i}}$ is the reflection coefficient at the Air /Material interface.

$\mathrm{T}_{\mathrm{i}}$ : The transmission matrix of a line of length $\mathrm{d}$.

$$
T_{i}=\left(\begin{array}{cc}
\exp \left(-\gamma_{i} d\right) & 0 \\
0 & \exp \left(\gamma_{i} d\right)
\end{array}\right)
$$

$\gamma_{0}$ and $\gamma_{\mathrm{i}}$ The propagation constants in the air and in the dielectric respectively were $\mathrm{i}=1$ or 2 .

Where

$\gamma_{0}=j \frac{2 \pi}{\lambda_{0}} \sqrt{1-\left(\frac{\lambda_{0}}{\lambda_{c}}\right)^{2}}$

and $\gamma_{i}=j \frac{2 \pi}{\lambda} \sqrt{\varepsilon_{r i}^{*} \mu_{r i}^{*}-\left(\frac{\lambda_{0}}{\lambda_{c}}\right)^{2}}$

$\varepsilon_{r i}^{*}=\varepsilon_{r i}^{\prime}-j \varepsilon_{r i}^{\prime \prime}$ is the complex relative permittivity of the standard dielectric samples $(i=1)$ and the material under test $(i=2) . \lambda_{c}$ and $\lambda_{0}$ are the cut-off wavelength of the rectangular waveguide and the length in free space, respectively.

The matrix product $\mathrm{M}_{1} \mathrm{M}_{2}^{-1}$ makes it possible to eliminate the error matrix $\mathrm{Y}$ as shown by relation:

$$
\operatorname{tr}\left(M_{1} M_{2}^{-1}\right)=\operatorname{tr}\left(X T_{\operatorname{ref} 1} T_{1} T_{\text {ref } 1}^{-1} T_{2} T_{\text {ref } 2}^{-1} T_{2}^{-1} X^{-1}\right)
$$

This last equation also shows that $\mathrm{M}_{1} \mathrm{M}_{2}^{-1}$ and $T_{\text {ref } 1} T_{1} T_{\text {ref } 1}^{-1} T_{2} T_{\text {ref } 2}^{-1} T_{2}^{-1} X^{-1}$ are similar, that is to say they have the same trace defined by the sum of the diagonal elements:

$$
\operatorname{tr}\left(M_{1} M_{2}^{-1}\right)=\operatorname{tr}\left(T_{\text {ref } 1} T_{1} T_{\text {ref } 1}^{-1} T_{2} T_{r e f 2}^{-1} T_{2}^{-1} X^{-1}\right)
$$

The relation (16) is a nonlinear equation whose only unknown is the permittivity complex $\varepsilon_{\mathrm{r} 2}^{*}$ of the material under test.

Equation (16) can be simplified if the air is taken as the reference dielectric during the first compute, then: $\varepsilon_{\mathrm{r} 1}^{*}=1, \gamma_{1}=\gamma_{0}$ and $\Gamma_{1}=0$.

Equation (17) becomes:

$$
\begin{aligned}
& \operatorname{tr}\left(M_{1} M_{2}^{-1}\right)=\operatorname{tr}\left(T_{1} T_{r e f 2}^{-1} T_{2}^{-1} T_{r e f 2}^{-1}\right)= \\
& =2 \frac{\Gamma_{2}^{2} \cosh \left[\left(\gamma_{0}+\gamma_{2}\right) d\right]-\cos \left[\left(\gamma_{0}-\gamma_{2}\right) d\right]}{\Gamma_{2}^{2}-1}
\end{aligned}
$$

\section{NUMERICAL CALCULATION AND ANALYSIS}

Our study focuses on determining the contrast effect on the effective dielectric permittivity of the mixture resulting from the numerical solution of the electrostatic global problem. In this paper, three composites of microwires inclusions of silicon carbide family are: 
Nicalon SiC fiber, Hi-Nicalon $\mathrm{SiC}$ fiber and SCS6 $\mathrm{SiC}$ fiber with a permittivity $\varepsilon_{2}=6,12,50$ respectively, occupying periodic positions in a ceramic material $\mathrm{SiC}$ of permittivity $\varepsilon_{1}=3$ have been investigated as shown in Figure 1. Both materials are homogeneous, lossless, and isotropic. Using electromagnetic simulation software and following the finite element method, we study the evolution of the effective permittivity depending on the volume fraction $\mathrm{p}$ of microwires inclusions.

Using finite element method, we split the composite model shown in Figure 1 into $\mathrm{N}$ finite elements (unit cell). The potential distribution in this space can be approximated inside each element using interpolation functions. By solving the matrix equations resulting from this discretization procedure, we obtain the potential and its normal derivation on each node of the mesh.
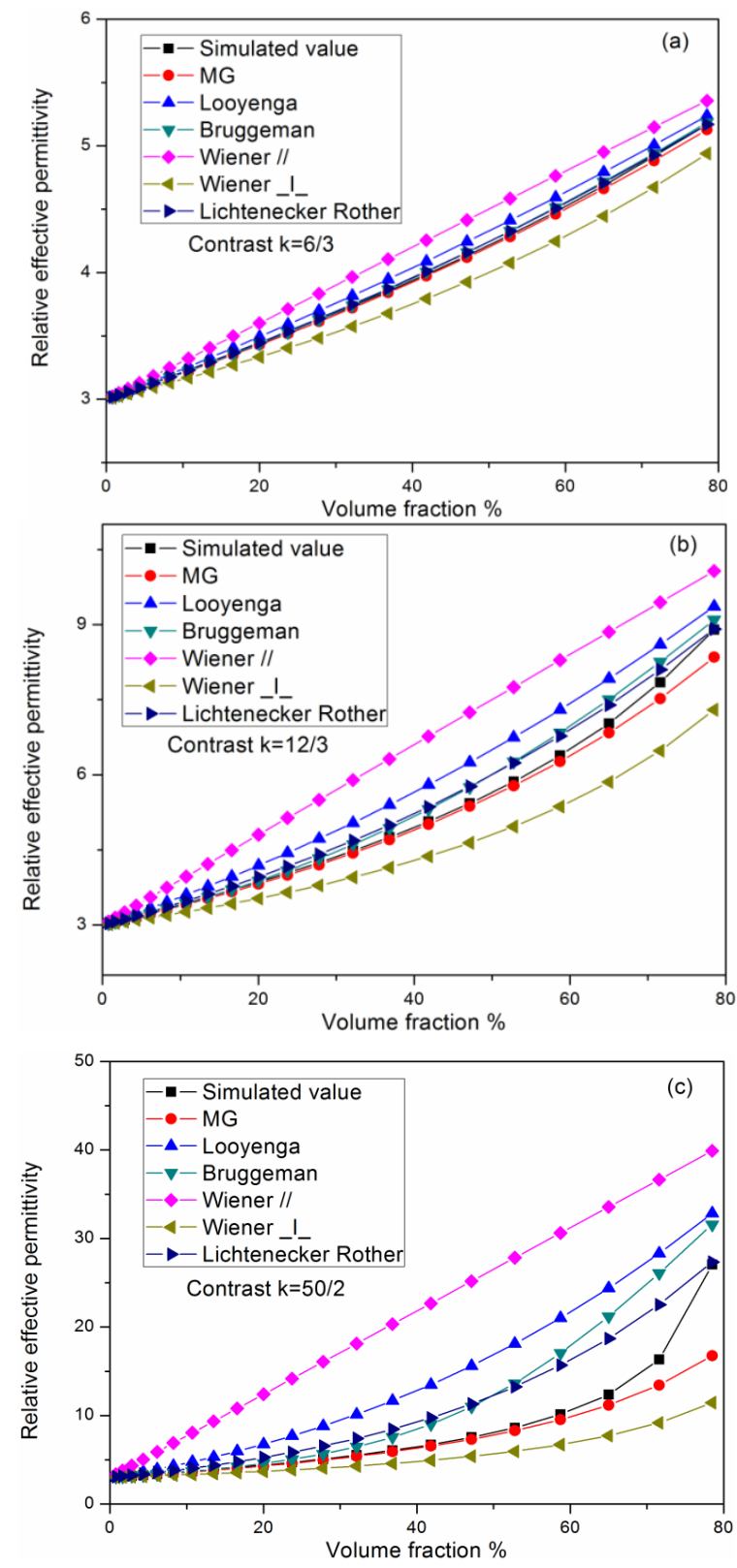

Figure 3. Variation of effective permittivity as a function of volume fraction for different contrast

Considering that the composite unit cell has dimensions of $(1 \times 1 \times 10) \mathrm{mm}^{3}$. In all simulations, the phases are initially discharged and no longer contain free charges. The external electric field is applied in the direction $(\mathrm{Oz})$ perpendicular to the revolution axes of cylindrical microwires. All results are obtained by EM simulation software that is three dimensional electromagnetic simulation software based on the finite element method installed on a personal computer.

Three contrasts $k=\frac{\varepsilon_{2}}{\varepsilon_{1}}=\frac{6}{3}, \frac{12}{3}$ and $\frac{50}{3}$ were analyzed by changing the volume fraction $\mathrm{p}$ of the microwire of radius $\mathrm{R}=50 \mu \mathrm{m}$ incorporated in the matrix from $0.78 \%$ to $78,5 \%$.

The effect of contrast $\mathrm{k}$ between the inclusions and the matrix and also the effect of the volume fraction $p$ of the effective permittivity will be present in Figure 3. The simulation results are compared with the different mixing laws.

In general, the values of the estimated effective permittivity are included between the Wiener terminals. For $\mathrm{k}<4$ (Figure $3 \mathrm{a}$ ), the contrast $\mathrm{K}$ is close to unity, The values of effective permittivity estimated according to the volume fraction are quasi-linear, in respect to all mixing laws, and the limits are narrow. On the one hand, for all contrast $6 / 2<\mathrm{k}<50 / 3$ the simulated permittivity is acceptable up to $30 \%$ the volume fraction with the laws of Bruggeman, Lichtenecker-Rother and $60 \%$ the volume fraction with the Maxwell-Garnett law. On the other hand, these mixing laws are unable to estimate the effective permittivity for the volume fractions of the whole interval for Looyenga law and more than $60 \%$ for the Maxwell-Garnet law and more than $30 \%$ for Bruggeman and Lichtenecker-Rother laws due to a divergence observed between the numerical results and mixing laws. This divergent behavior marked in Figure $3 \mathrm{c}$ is noticed mainly due to the multipolar interactions between microwires that become very significant at high concentrations [18]. Induced electrostatic interactions between small uncharged dielectric Microwire in an electric field can be represented by multipole including the familiar dipole and quadrupole and other higher-order terms. The interwire forces can be determined taking into account the multipole interactions that become very strong when the microwires approach each other in the presence of an electric field. All the inclusions are considered equivalent to a single dipole isolated in the matrix, whose polarization is the sum of individual polarizabilities.

For the McLachlan law, we propose to make an amendment which consists of taking into consideration that the exponent $t$ is fixed and the exponent $s$ is a dependent variable in function to volume fraction and contrast. We can maintain the exponent $\mathrm{t}=1,2,3$ constant and seek values of the exponent $s$ that will satisfy McLachlan equation for $\mathrm{k}=6 / 3,12 / 3$ and 50/3 by reproducing the same values of permittivity obtained by simulation. Figure 4 Shows respectively the variations of $\mathrm{s}(\mathrm{p}, \mathrm{k})$ for $\mathrm{t}=1,2$ and 3. Exponent $\mathrm{s}$ was determined by using a numerical program for every calculated permittivity contrast according to volume fraction.

For $\mathrm{t}=1$, the exponent $\mathrm{s}$ does not necessarily depend on contrast variation. $s$ increases rapidly from 0.3 to 0.9 up to $20 \%$ according to volume fraction and thereafter it decreases at 0.7 for strong contrasts $k=50 / 3$. Contrary, 
$\mathrm{s}$ has remained almost constant at 0.9 for low contrast $\mathrm{k}$ $=6 / 3,12 / 3$. This value increases in a remarkable way when the value of the exponent $t$ increases with decrease of contrast.
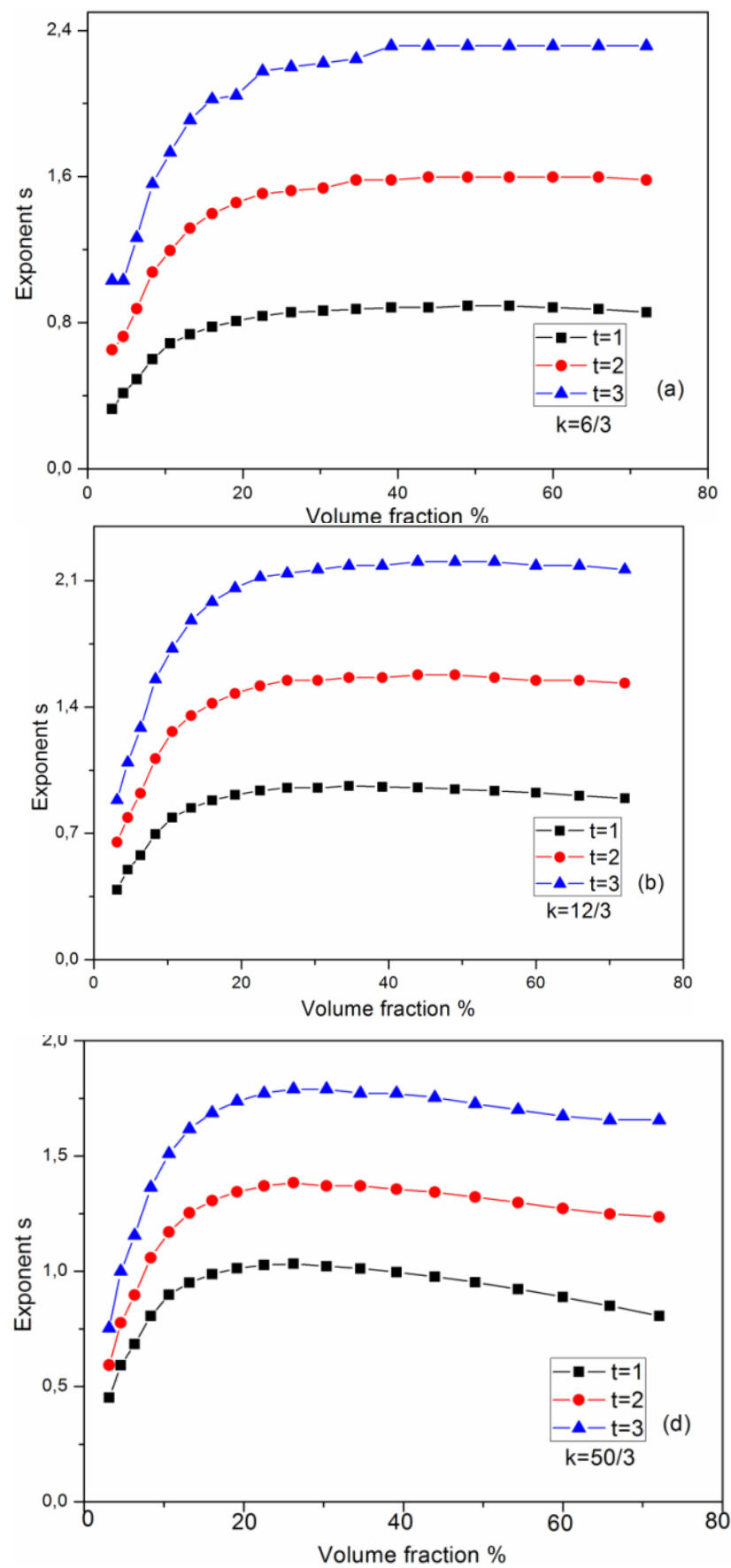

Figure 4. Variation of the exponent $s$ as a function of volume fraction for different contrasts

From the spectra of the Figure 5, it is clear that the simulated value of the effective permittivity is in good agreement with the McLachlan model according to the value of the exponent $\mathrm{s}$ for $\mathrm{t}=1$. This study shows a method which depends on the volume fraction and permittivity contrast with the simulation results calculated using the exponent $\mathrm{s}$ and $\mathrm{t}$.

This model finds the values of $\mathrm{s}$ such that the McLachlan equation allows to reach the value of the effective permittivity where interactions inclusionsinclusions and inclusions matrix are taken into account.
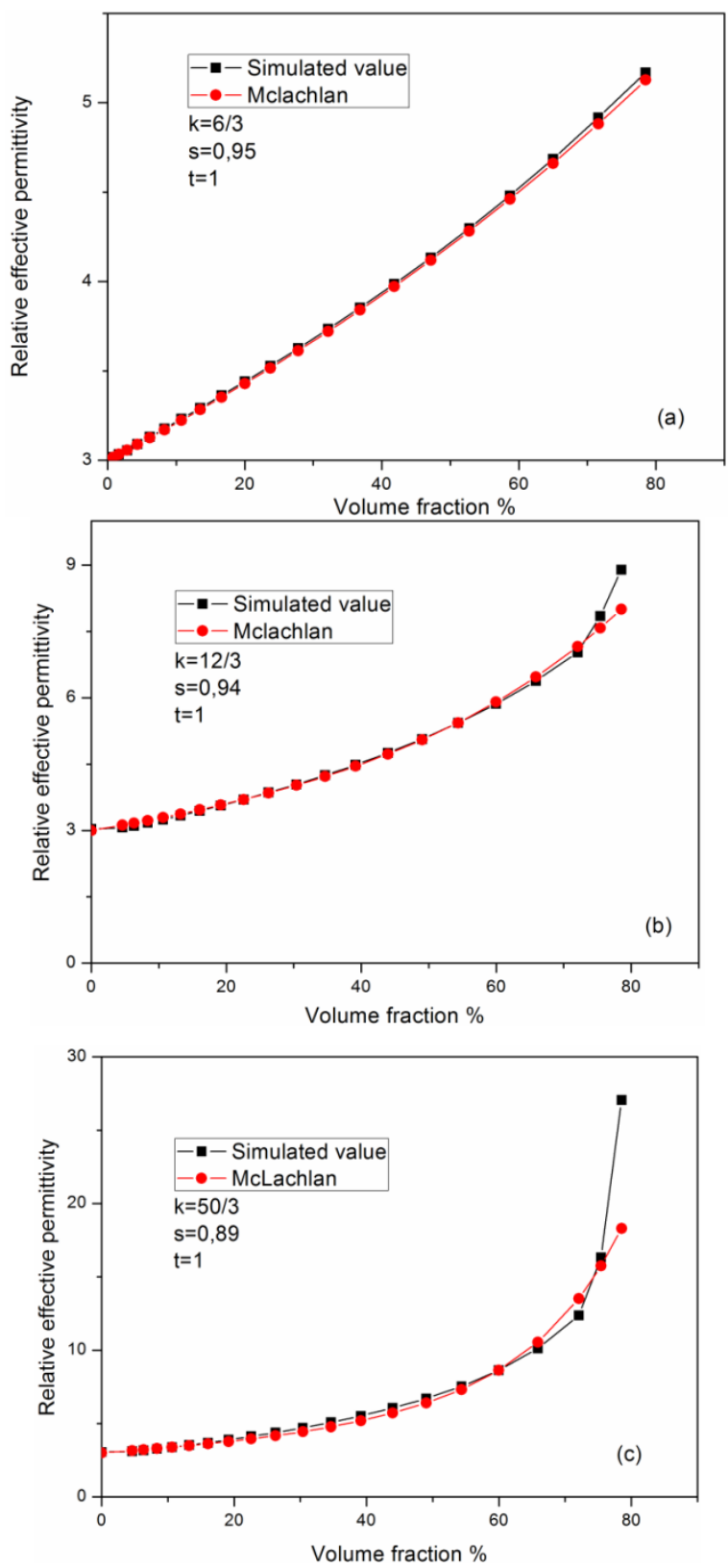

Figure 5. Interphase effective permittivity dependence of the exponent $s$ as a function of the volume fraction

Figure 6 shows the real part of the complex permittivity, as a function of frequency, for composites with different concentrations of Nicalon $\mathrm{SiC}$ fiber, $\mathrm{Hi}$ Nicalon SiC fiber and SCS6 SiC respectively in the host matrix of $\mathrm{SiC}$.

In this study we tried different mixing laws to adapt the simulated results. Table 1 shows the fits using these laws at the $\mathrm{X}$ band. The estimated minimal mean square errors allow us to conclude that Looyenga's law corresponds to the data. The obtained parameter $h$, in equation (4) was 1.76 , which indicates that the shape of the particles is far from spherical for which $\mathrm{h}$ is equal to 3 [12].

Unlike the other models of mixing laws which indicate that the shape of the particles is spherical, the generalized Looyenga model takes into account the statistical nature of the dielectric permittivity of the medium, whose geometric form of inclusions does not play an important role in the determination of the macroscopic dielectric behavior of the mixture. 
Table 1. Mixture laws fit of the Simulated real part of the complex permittivity

\begin{tabular}{|c|c|c|c|c|c|c|c|c|c|}
\hline $\begin{array}{l}\text { Composite } \\
\text { and } \\
\text { Contrast K }\end{array}$ & $\begin{array}{l}\text { Percentage } \\
\text { of } \\
\text { inclusions } \\
(\%)\end{array}$ & $\begin{array}{l}\text { Simulated } \\
\text { average } \\
\text { value of real } \\
\text { part of } \\
\text { permittivity } \\
\text { in X band }\end{array}$ & MG & $\begin{array}{c}\text { Generalised } \\
\text { Looyenga }\end{array}$ & $\begin{array}{l}\text { Wiener } \\
\quad / /\end{array}$ & $\begin{array}{l}\text { Wiener } \\
\perp\end{array}$ & Bruggeman & $\begin{array}{c}\text { Lichtenecker } \\
\text { Rother }\end{array}$ & Mclachlan \\
\hline \multirow{3}{*}{$\begin{array}{l}\text { Nicalon } \\
\text { SiCfiber/SiC } \\
\mathrm{K}=6 / 3\end{array}$} & 0.78 & 3.0187 & 3.0157 & 3.0184 & 3.0235 & 3.0118 & 3.0157 & 3.0163 & 3.0157 \\
\hline & 31.4 & 3.8244 & 3.7206 & 3.8172 & 3.9650 & 3.5750 & 3.7413 & 3.7494 & 3.7206 \\
\hline & 71.54 & 5.0172 & 4.8819 & 5.0069 & 5.1489 & 4.6739 & 4.9408 & 4.9289 & 4.8819 \\
\hline \multirow{3}{*}{$\begin{array}{c}\text { Hi-Nicalon } \\
\text { SiCfiber/SiC } \\
\mathrm{K}=12 / 3 \\
\end{array}$} & 0.78 & 3.03791 & 3.0284 & 3.0417 & 3.0706 & 3.0177 & 3.0284 & 3.0328 & 3.0012 \\
\hline & 31.4 & 4.5846 & 4.4351 & 4.5827 & 5.8952 & 3.9539 & 4.6061 & 4.6860 & 4.4529 \\
\hline & 71.54 & 8.6001 & 7.5222 & 8.6036 & 9.4467 & 6.4826 & 8.2546 & 8.0980 & 7.5804 \\
\hline \multirow{3}{*}{$\begin{array}{c}\mathrm{SCS} 6 \mathrm{SiC} / \mathrm{SiC} \\
\mathrm{K}=50 / 3\end{array}$} & 0.78 & 3.1297 & 3.0420 & 3.1112 & 3.3691 & 3.0223 & 3.0423 & 3.0670 & 3.0017 \\
\hline & 31.4 & 9.9561 & 5.394 & 10.1257 & 18.1198 & 4.3004 & 6.4599 & 7.4163 & 5.1927 \\
\hline & 71.54 & 28.3614 & 13.4479 & 28.3180 & 36.6662 & 9.1834 & 26.0832 & 22.5079 & 15.7383 \\
\hline
\end{tabular}
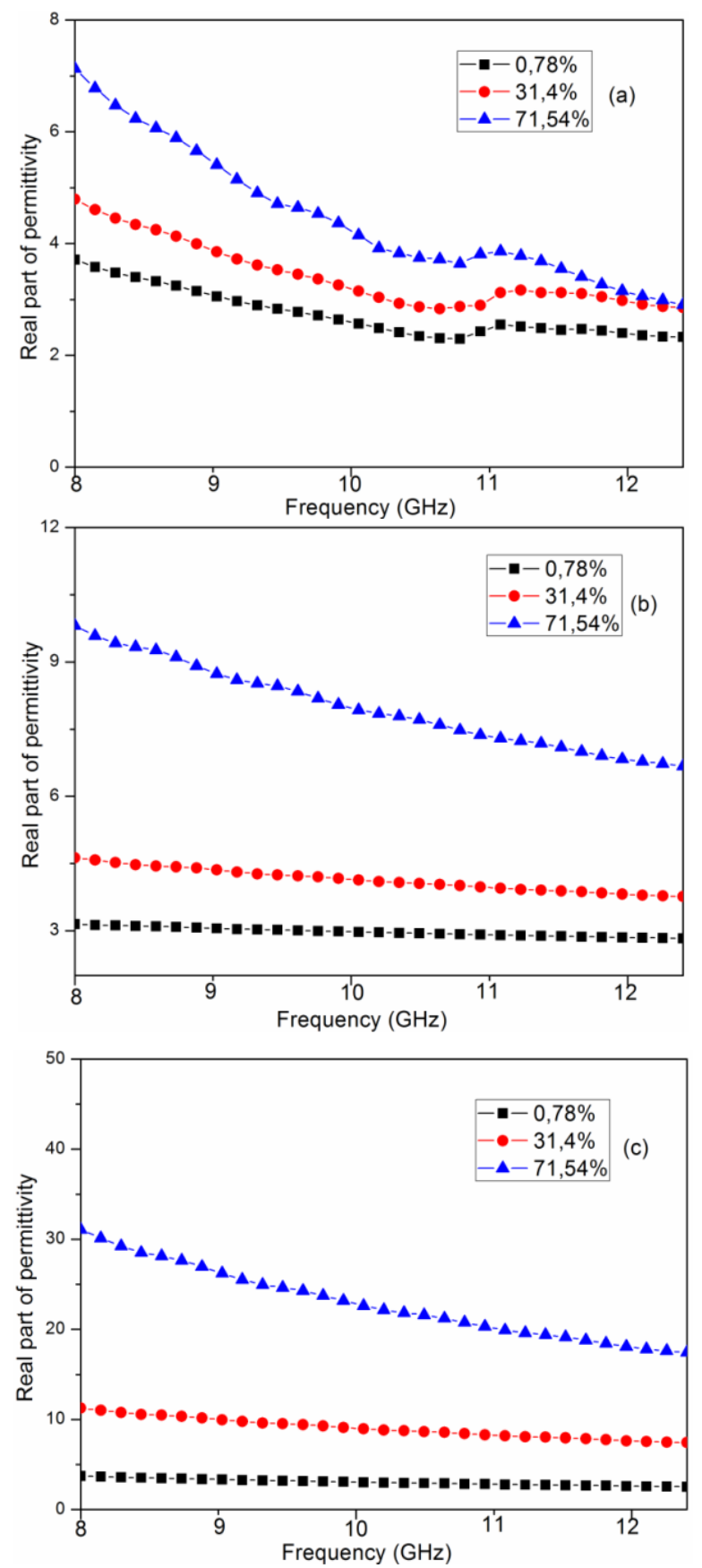

Figure 6. Real part of the complex permittivity as a function of frequency, for different composites : (a) Nicalon SiC fiber, (b) Hi-Nicalon SiC fiber, and (c) SCS6 SiC

\section{CONCLUSION}

This article reports on a study of the dielectric properties of fiber $\mathrm{SiC}$ dispersions in an insulating $\mathrm{SiC}$ ceramic matrix $(\mathrm{SiCf} / \mathrm{SiC})$ at microwave frequencies. In the first part of this work, we determined the effective permittivity as a function of the volume fraction of the inclusions and their contrast permittivity and compare it with different numerical results determined by mixing laws. In high concentrations, the multipolar interactions become very significant and most of the mixtures rules are unable to predict the dielectric behavior of heterogeneous systems. If the values of the exponents $\mathrm{s}$ and $t$ are adjusted, McLachlan's theory is able to predict the effective permittivity of the structures studied, even for a high volume fraction and a high contrast. In the second part, we studied the microwave dielectric properties of these ceramic composites as a function of fraction volume of the inclusions. Dielectric properties of these composites can be accurately adjusted by the generalized Looyenga law. The values obtained for the parameter exponent $h$ of this law make it possible to infer the shape of the particles.

\section{REFERENCES}

[1] Dinulović, M., Rašuo, B.: Dielectric properties modeling of composite materials, FME Transactions, Vol. 37 No 3, pp. 113-118, 2009.

[2] Kärkkäinen, K., Sihvola, A., Nikoskinen, K.: Effective permittivity of mixtures: numerical validation by the FDTD method, IEEE Trans. Geosci. Remote Sensing, Vol.38, No. 3, pp.1303-1308, 2000.

[3] Myroshnychenko, V., Brosseau, C.: Finite-element method for calculation of the effective permittivity of random inhomogeneous media, Phys. Rev. E, Vol.7, No.1, pp. 016701, 2005.

[4] Dinulović, M., Rašuo, B., Dielectric modeling of multiphase composites, Composite Structures, Volume 93, Issue 12, pp. 3209-3215, November 2011.

[5] Elboubakraoui, M. C. et al.: Electro-magnetic Properties of Polymer Composites Co52Cr22Ni10 W7,5Fe1,5 and Fe59Cr21,5Ni7Si1Mn10 at $\mathrm{Ku}$ Band, FME Transactions, Vol. 45 No 4, pp. 678-683, 2017.

[6] Jylhä, L., Sihvola, A.: Numerical modeling of disordered mixture using pseudorandom simulations, IEEE 
Trans. Geosci. Remote Sensing Vol. 43, No. 1, pp. 5964, 2005.

[7] Petrov, V.M., Gagulin, V.V.: Microwave absorbing materials, Inorg. Mater., Vol. 37, No. 2, pp. 93-98, 2001.

[8] Luo, F., Zhu, D.M, Zhou, W.C.: A two-layer dielectric absorber covering a wide frequency range, Ceram. Int. Vol. 33, No. 2 , pp.197-200, 2007.

[9] Liu, X., wu, Y., wang, X., Li, R., Zhang, Z.: Effect of interphase on effective permittivity of composites, J. Phys. D: Appl. Phys. Vol. 44, No. 11, pp. 115402, 2011.

[10] Michel, B., Lakhtakia, A. : On the application of the strong property fluctuation theory for homogenizing chiral-in-chiral composites, J. Phys. D: Appl. Phys. Vol. 29, No.6, pp. 1431-1440, 1996.

[11] Wu, Y., Zhao, X., Li, F., Fan, Z.: Evaluation of Mixing Rules for Dielectric Constants of Composite Dielectrics by MC-FEM Calculation on 3D Cubic Lattice, J. Electro. ceram. Vol. 11, No.3, pp. 227-239, 2003.

[12] Amaral, F., Rubinger, C.P.L., Henry, F., Costa, L.C., Valente, M.A., Barros, T. A.: Dielectric properties of polystyrene-CCTO composite J. Non-Cryst. Solids, Vol. 354, No. 47, pp. 5321-5322, 2008.

[13] Calame, J. P.: Finite difference simulations of permittivity and electric field statistics in ceramic polymer composites for capacitor applications, J. Appl. Phys., Vol. 99, No.8, pp. 084101, 2006.

[14]Bishay, S. T.: Numerical Methods for Calculation of Cole-Cole Parameters, Egypt J. Sol., Vol. 23, No. 2, pp 179-188, 2000.

[15] McLachlan, D. S.: An equation for the conductivity of binary mixtures with anisotropic grain structures, J. Phys. C: Solid State Phys. Vol. 20 pp. 865-877, 1987.

[16] Wu J., McLachlan D.S.: Percolation exponents and thresholds obtained from the nearly ideal continuum percolation system graphite-boron nitride, Phys. Rev. B, Vol. 56, No. 3, pp. 1236-1248, 1997.

[17] Castellano-Hernandez, E., Sacha, G.M. : Ultrahigh dielectric constant of thin films obtained by electrostatic force microscopy and artificial neural networks, App. Phys. Lett. Vol. 100, No. 2, pp. 023101, 2012.

[18] Jebbor, N., Bri, S.: Effective Permittivity of Periodic Composite Materials; Numerical Modeling by the Finite Element Method, J. Electrostat. Vol. 70, No. 4, pp. 393-399, 2012.

[19] Serdyuk, Y.V., Podoltsev, A.D., Gubanski S.M.: Numerical simulations of dielectric properties of composite material with periodic structure, J. Electrostat. Vol. 63, No. 11, pp.1073-1091, 2005.
[20]Mejdoubi, A., Brosseau, C. : Finite-element simulation of the depolarization factor of arbitrarily shaped inclusions, Phys. Rev. E, Vol. 74, No. 3 pp. 031405, 2006.

[21]Zhao, X., Wu, Y., Fan, Z., Li, F.: Threedimensional simulations of the complex dielectric properties of random composites by finite element method, J. Appl. Phys., Vol. 95 ,No. 12, pp. 8110-8117, 2004.

[22] Hasar, U.C.: On the application of microwave calibration-independent measurements for noninvasive thickness evaluation of medium- or low-loss solid materials, Prog. Electromag. Res., Vol. 91, pp. 377-392, 2009.

[23] Jebbor, N., Bri, S., Nakheli, A., Bejjit, L., Hdddad, M., Mamouni, A.: Complex permittivity determination with the transmission/reflection method, Int. J. Emerg. Sci., Vol. 1 No. 4, pp. 682-695, 2011.

[24] Jebbor, N., Bri, S., Sánchez, A.M., Chaibi, M.: Afast calibration-independent method for complex permittivity determination at microwave frequencies, Measurement, Vol. 46, pp. 2206-2209, 2013.

\section{NOMENCLATURE}

$\begin{array}{ll}\text { SiCf } & \text { Sillicon Carbide }(\mathrm{SiC}) \text { offer } \\ \mathrm{MG} & \text { Maxwell-Garnett } \\ \mathrm{S}_{11} & \text { Reflection parameter } \\ \mathrm{S}_{21} & \text { Transmission parameter }\end{array}$

\section{ДИЕЛЕКТРИЧНА СВОЈСТВА $\mathrm{SiCf} / \mathrm{SiC}$ КОМПОЗИТА}

\section{М.Ц. Ел Бубакрауи, С. Бри, Ј. Фоши}

Рад приказује истраживање микроталасних диелектричних својстава три диелектрична композита периодичне структуре са $\mathrm{SiC}(\mathrm{SiCf} / \mathrm{Sic})$ керамичком матрицом ојачаном влакнастим $\mathrm{SiC}$ дисперзијама. Вредности комплексне пропусности добијене симулацијом упоређене су са вредностима добијеним различитим законима мешања помоћу методе коначних елемената. Меклокланова теорија може да предвиди степен ефикасности структура, чак и за фракције велике волуминозности и контраста. Понашање диелектричних својстава ових композита у фреквенцијском х појасу микроталаса може се прецизно прилагодити помоћу генерализованог Луенгиног закона уколико се подеси вредност експонента h. Вредности експонента добијене овим законом омогућавају доношење закључка о облику честица. 